\title{
PENEMUAN HUKUM HAKIM MAHKAMAH KONSTITUSI DALAM \\ PUTUSAN MAHKAMAH KONSTITUSI NOMOR 21/PUU-XII/2014.MK \\ KASUS PROYEK BIOMEDIASI PT.CHEVRON BACHTIAR ABDUL FATAH
}

\author{
Ujang Suratno \\ Universitas Wiralodra Indramayu \\ faujura_1804@gmail.com
}

\begin{abstract}
Judicial authority in Indonesia is carried out by a Supreme Court and the Constitutional Court which has the authority to examine laws against the 1945 Constitution of the Republic of Indonesia and decide on the authority dispute of state institutions whose authority is granted by the 1945 Constitution of the Republic of Indonesia. The Constitutional Court in examining the Law against the 1945 Constitution became a polemic related to the prejudicial object which was finally answered through the decision of the Constitutional Court (MK) number 21 / PUU-XII / 2014. The Constitutional Court granted part of the application for corruption convictions in the case of PT Chevron Bachtiar's Abdul Fatah biomediation project, one of which examined the prejudicial object provisions which were polemic, especially after the South Jakarta District Court's prejudicial has canceled the status of suspect Commissioner Budi Gunawan (BG) by the KPK.

This study is a legal research using a normative juridical approach and descriptive analytical research specifications. The data used in this study are secondary data consisting of primary, secondary and tertiary legal materials. Data obtained through library studies and field research in the form of legislation, books, journals, and authoritative electronic media.

The results of this study are 2 (two) explanations, namely First, Constitutional Court Judges have made legal inventions by providing interpretations and limitations on what can be the object of prejudicial in criminal procedural law by testing it against the constitution and seeing whether the KUHAP Articles tested are contradictory with constitutional rights. Secondly, the Constitutional Court uses several interactive techniques used by member judges in decision number 21 / PUU-XII / 2014. In the joint decision, the judges used Authentic, Systematic, Grammatical, Historical, Extensively and sociological interpretation techniques. This can be seen in the decision of point one stating a phrase which means interpreting the law using grammatical techniques.
\end{abstract}

Keywords: Invention of Law, Constitutional Court, Prejudicial Object

\section{PENDAHULUAN}

Kekuasaan kehakiman di Indonesia dilaksanakan oleh sebuah Mahkamah Agung dan badan peradilan yang berada di bawahnya dalam lingkungan peradilan umum, lingkungan peradilan agama, lingkungan peradilan militer, lingkungan peradilan tata usaha negara, 
dan oleh sebuah Mahkamah Konstitusi. Mahkamah Konstitusi berwenang untuk menguji undang-undang terhadap Undang-Undang Dasar Negara Republik Indonesia Tahun 1945 dan memutus sengketa kewenangan lembaga negara yang kewenangannya diberikan oleh Undang-Undang Dasar Negara Republik Indonesia Tahun 1945.

Pasal 24 ayat (1) Undang-Undang Dasar 1945 menyatakan "Kekuasaan kehakiman merupakan kekuasaan yang merdeka untuk menyelenggarakan peradilan guna menegakkan hukum dan keadilan”.

Pasal 24 ayat (2) yang menyatakan:

"Kekuasaan kehakiman dilakukan oleh sebuah Mahkamah Agung dan badan peradilan yang berada di bawahnya dalam lingkungan peradilan umum, lingkungan peradilan agama, lingkungan peradilan militer, lingkungan peradilan tata usaha negara, dan oleh sebuah Mahkamah Konstitusi."

Pasal 1 ayat (5) Undang-Undang Nomor 22 Tahun 2004 tentang Komisi Yudisial yang dimaksud dengan hakim adalah hakim agung dan hakim pada badan peradilan di semua lingkungan peradilan yang berada di bawah Mahkamah Agung serta Hakim Mahkamah Konstitusi sebagimana dimaksud dalam Undang Undang Dasar Negara Republik Indonesia Tahun 1945. Sedangkan menurut Undang-Undang Nomor 48 Tahun 2009 tentang Kekuasaan Kehakiman dalam Pasal 1 angka 5:

"Hakim adalah hakim pada Mahkamah Agung dan hakim pada badan peradilan yang berada di bawahnya dalam lingkungan peradilan umum, lingkungan peradilan agama, lingkungan peradilan militer, lingkungan peradilan tata usaha negara, dan hakim pada pengadilan khusus yang berada dalam lingkungan peradilan tersebut."

Pasal 1 angka 6 menyebutkan bahwa Hakim Agung adalah hakim pada Mahkamah Agung. Pasal 1 angka 7, Hakim Konstitusi adalah hakim pada Mahkamah Konstitusi.

Hakim dan Hakim Konstitusi memiliki tugas dan kewenangan yang terdapat dalam Pasal 5 Undang-Undang Nomor 48 Tahun 2009 tentang Kekuasaan Kehakiman, yaitu:

(1) Hakim dan hakim konstitusi wajib menggali, mengikuti, dan memahami nilainilai hukum dan rasa keadilan yang hidup dalam masyarakat.

(2) Hakim dan hakim konstitusi harus memiliki integritas dan kepribadian yang tidak tercela, jujur, adil, profesional, dan berpengalaman di bidang hukum.

(3) Hakim dan hakim konstitusi wajib menaati Kode Etik dan Pedoman Perilaku Hakim.

Sesuai dengan Pasal 19 Undang-Undang RI Nomor 48 tahun 2009 tentang Kekuasaan Kehakiman maka Hakim adalah pejabat Negara yang melakukan kekuasaan kehakiman yang diatur dalam undang-undang. 
Tugas Pokok Hakim : ${ }^{1}$

1. Menerima berkas Perkara

2. Memeriksa perkara yang diajukan kepadanya

3. Memutus perkara yang diajukan kepadanya

Dimana semua hal tersebut merupakan rangkaian dari menerima dan mengadili (baca : memeriksa dan memutus sesuai dengan KUHAP) suatu perkara yang diajukan kepadanya. Hakim dilarang menolak suatu perkara dengan alasan tidak ada hukum yang mengatur, seperti yang tercantum dalam Pasal 10 Undang-Undang Nomor 48 Tahun 2009 tentang Kekuasaan Kehakiman :

(1)Pengadilan dilarang menolak untuk memeriksa, mengadili, dan memutus suatu perkara yang diajukan dengan dalih bahwa hukum tidak ada atau kurang jelas, melainkan wajib untuk memeriksa dan mengadilinya.

(2)Ketentuan sebagaimana dimaksud pada ayat (1) tidak menutup usaha penyelesaian perkara perdata secara perdamaian.

Mahkamah Konstitusi Republik Indonesia adalah lembaga (tinggi) negara yang baru yang sederajat dan sama tinggi kedudukannya dengan Mahkamah Agung (MA). Menurut ketentuan Undang-Undang Dasar Negara Republik Indonesia Tahun 1945 pasca Perubahan Keempat (Tahun 2002), dalam struktur kelembagaan Republik Indonesia terdapat (setidaknya) 9 (sembilan) buah organ negara yang secara langsung menerima kewenangan langsung dari Undang-Undang Dasar. Kesembilan organ tersebut adalah (i) Dewan Perwakilan Rakyat, (ii) Dewan Perwakilan Daerah, (iii) Majelis Permusyawaratan Rakyat, (iv) Badan Pemeriksa Keuangan, (v) Presiden, (vi) Wakil Presiden, (vii) Mahkamah Agung, (viii) Mahkamah Konstitusi, dan (ix) Komisi Yudisial. ${ }^{2}$

O.C. Kaligis dalam bukunya yang berjudul Mahkamah Konstitusi Praktik Beracara \& Permasalahannya mengatakan bahwa MA dan MK sama-sama merupakan pelaksana cabang kekuasaan kehakiman (judiciary) yang merdeka dan terpisah dari cabang-cabang kekuasaan lain, yaitu pemerintah (executive) dan lembaga permusyawaratan perwakilan

${ }^{1}$ Pengadilan Negeri Toli-Toli, Dalam Artikelnya Yang Berjudul "Uraian Tugas Hakim" Http://Www.Pn-Tolitoli.Go.Id/Index.Php?Option=Com_Content\&View=Article\&Id=119\&Itemi $\mathrm{D}=110$. Diakses Pada Tanggal 19 November 2016.

${ }^{2}$ Mahkamah Konstitusi, Dalam Artikelnya Yang Berjudul "Kedudukan Mahkamah Konstitusi Dalam Struktur Ketatanegaraan Indonesia" Http://Www.Mahkamahkonstitusi.Go.Id/Index.Php?Page=Web.Berita\&Id=11779\#.WDC3L6J 95sm. Diakses Pada Tanggal 19 November 2016. 
(legislature). Namun, struktur kedua organ kekuasaan kehakiman ini terpisah dan berbeda sama sekali satu sama lain. ${ }^{3}$

Menurut Pasal 29 Undang-Undang Nomor 48 Tahun 2009 tentang Kekuasaan Kehakiman kewenangan Mahkamah Konstitusi diantaranya:

(1)Mahkamah Konstitusi berwenang mengadili pada tingkat pertama dan terakhir yang putusannya bersifat final untuk:

a. Menguji undang-undang terhadap Undang-Undang Dasar Negara Republik Indonesia Tahun 1945;

b. Memutus sengketa kewenangan lembaga negara yang kewenangannya diberikan oleh Undang-Undang Dasar Negara Republik Indonesia Tahun 1945;

c. Memutus pembubaran partai politik;

d. Memutus perselisihan tentang 77hasil pemilihan umum; dan kewenangan lain yang diberikan oleh undang-undang.

(2)Selain kewenangan sebagaimana dimaksud pada ayat (1), Mahkamah Konstitusi wajib memberikan putusan atas pendapat Dewan Perwakilan Rakyat bahwa Presiden dan/atau Wakil Presiden diduga telah melakukan pelanggaran hukum berupa pengkhianatan terhadap negara, korupsi, penyuapan, tindak pidana berat lainnya atau perbuatan tercela, dan/atau tidak lagi memenuhi syarat sebagai Presiden dan/atau Wakil Presiden.

Polemik penetapan tersangka sebagai salah satu objek praperadilan akhirnya terjawab lewat putusan Mahkamah Konstitusi (MK) bernomor 21/PUU-XII/2014. MK mengabulkan sebagian permohonan terpidana korupsi kasus proyek biomediasi PT Chevron Bachtiar Abdul Fatah yang salah satunya menguji ketentuan objek praperadilan terutama pasca putusan praperadilan PN Jakarta Selatan yang membatalkan status tersangka Komjen (Pol) Budi Gunawan (BG) oleh KPK. ${ }^{4}$

Dalam putusannya, Mahkamah Konstitusi menyatakan inkonstitusional bersyarat terhadap frasa "bukti permulaan", "bukti permulaan yang cukup", dan "bukti yang cukup" dalam Pasal 1 angka 14, Pasal 17, dan Pasal 21 ayat (1) KUHAP sepanjang dimaknai minimal dua alat bukti sesuai Pasal 184 KUHAP. Pasal 77 huruf a KUHAP dinyatakan inkontitusional bersyarat sepanjang dimaknai termasuk penetapan tersangka, penggeledahan, dan penyitaan. "Menolak permohonan untuk selain dan selebihnya," Ketua MK Arief Hidayat saat membacakan amar putusan di ruang sidang MK, Selasa (28/4). Mahkamah beralasan KUHAP tidak memberi penjelasan mengenai batasan jumlah (alat bukti) dari frasa "bukti permulaan", "bukti permulaan yang cukup", dan "bukti yang

3 O.C. Kaligis, Mahkamah Konstitusi Praktik Beracara \& Permasalahannya, O.C. Kaligis \& Associates: Jakarta, 2005, hlm. 71.

${ }^{4}$ Agus Sahbani, Dalam Artikelnya Yang Berjudul "MK 'Rombak' Bukti Permulaan dan Objek Praperadilan" http://www.hukumonline.com/berita/baca/lt553f5575acd85/mk-rombak-bukti-permulaandan-objek-praperadilan. Diakses Pada Tanggal 19 November 2016. 
cukup”. Berbeda dengan Pasal 44 ayat (2) UU No. 30 Tahun 2002 tentang Komisi Pemberantasan Tindak Pidana Korupsi yang mengatur secara jelas batasan jumlah alat bukti, yakni minimal dua alat bukti.

Adapun permasalah yang timbul dari uraian diatas diantaranya:

1. Apa hukum yang ditemukan hakim MK dalam putusan no 21/PUU-XII/2014?

2. Bagaimana metode penemuan hukum yang digunakan hakim MK dalam putusan no 21/PUU-XII/2014?

\section{METODE}

Penelitian ini menggunakan metode pendekatan Yuridis Normatif, yaitu penelitian dengan pendekatan yang lebih ditekankan pada data-data sekunder berupa bahan-bahan hukum primer, sekunder maupun tersier. Pada penelitian hukum normatif, bahan pustaka merupakan data dasar dalam (ilmu) penelitian yang digolongkan sebagai data sekunder. ${ }^{5}$ Spesifikasi penelitian ini adalah deskriptif analitis, yaitu penelitian yang bertujuan menggambarkan mengenai fakta-fakta disertai analisis yang akurat mengenai peraturan perundang-undangan yang berlaku baik nasional maupun internasional dihubungkan dengan teori-teori hukum yang berkaitan dengan pembangunan hukum. Soerjono Soekanto mengemukakan bahwa penelitian deskriptif yaitu memberikan data yang seteliti mungkin tentang manusia, keadaan dan gejala - gejalan lainnya, dengan tujuan mempertegas hipotesa - hipoesa supaya dapat membantu dalam memperkuat teori - teori lama, atau dalam kerangka menyusun teori baru. ${ }^{6}$

Teknik pengumpulan data dilakukan melalui Penelitian kepustakaan dan Penelitian di lapangan. Penelitian kepustakaan dilakukan untuk memperoleh bahan-bahan hukum baik primer, sekunder, maupun tersier. Bahan hukum primer adalah bahan-bahan yang berasal dari peraturan perundang-undangan, konvensi internasional, perjanjian internasional yang relevan. Bahan hukum sekunder yakni terdiri dari doktrin-doktrin, pendapat para ahli yang dapat terlihat dalam buku-buku hukum dan makalah-makalah yang ditulis oleh para ahli, karangan berbagai panitia pembentukan hukum, hasil penelitian hukum, RUU dan lainlain yang dapat memberikan penjelasan mengenai bahan hukum primer. Di samping itu dikaji pula bahan hukum tersier, yakni berupa pendapat-pendapat atau opini

\footnotetext{
${ }^{5}$ Soerjono Soekanto dan Sri Maudji, Penelitian Hukum Normatif Suatu Tinjauan Singkat, Jakarta: Raja Grafindo Persada, 1985, hlm 24

${ }^{6}$ Soerjono Soekanto, Pengantar Penelitian Hukum, Jakarta: Universitas Indonesia Press, 1984, hlm 10.
} 
masyarakat yang ada di dalam majalah-majalah dan surat kabar, kamus, ensiklospedi, yang dapat memberikan petujuk maupun penjelasan terhadap bahan hukum primer maupun sekunder.

Teknis Analisis data yang digunakan dalam penelitian ini adalah deskriptif analisis normatif, yakni pemaparan dan penggambaran peraturan perundang-undangan yang berkitan dengan pembentukan hukum yang dianalsis berdasarkan teori-teori hukum.

\section{PEMBAHASAN}

\subsection{Hukum Yang Ditemukan Hakim MK Dalam Putusan No. 21/PUU-XII/2014}

Pada hakikatnya proses judicial review atau pengujian Undang-Undang terhadap Undang-Undang Dasar adalah bentuk pengujian terhadap Undang-Undang yang dianggap bertentangan dengan hak konstitusional warga negara.

Terkait dengan pengujian yang dimohonkan oleh para pemohon dalam Putusan No 21/PUU-XII/2014, para pemohon melakukan pengujian terhadap sejumlah Pasal KUHAP. Pemohon menganggap bahwa Pasal-Pasal yang diuji telah merugikan hak konstitusional Pemohon. Jika tidak diberi tafsir yang jelas atau batasan yang pasti akan menjadi sarana pelanggaran terhadap hak asasi manusia atas nama penegakan hukum yang akan terjadi terus menerus.

Pengujian ini juga tidak terlepas dari perdebatan serta polemik penetapan tersangka sebagai salah satu objek praperadilan terutama pasca putusan praperadilan PN Jakarta Selatan yang membatalkan status tersangka Komjen (Pol) Budi Gunawan (BG) oleh KPK. Kemudian permasalahan penafsiran terkait objek peradilan ini dimohonkan oleh terpidana korupsi kasus proyek biomediasi PT Chevron Bachtiar Abdul Fatah yang salah satunya menguji ketentuan objek praperadilan.

Pemohon dalam permohonannya mendalilkan bahwa dalam beberapa Pasal yang diujikan tersebut penting untuk memperhatikan hak-hak konstitusional dari seorang warga negara. Hukum acara pidana dirancang untuk memastikan proses hukum yang adil dan konsisten yang biasa disebut sebagai "due process of law" untuk mencari keadilan yang hakiki dalam semua perkara yang diproses dalam penyelidikan hingga proses pengadilan. Hukum acara pidana dalam hal ini KUHAP merupakan implementasi dari penegakan dan perlindungan HAM yang merupakan ketentuan konstitusional dalam UUD 1945 maka jika terdapat ketentuan dalam KUHAP yang bertentangan dengan prinsip due process of law dan tidak memberikan kepastian hukum yang adil maka dengan sendirinya ketentuan

\footnotetext{
${ }^{5}$ Soerjono Soekanto dan Sri Mamuji, Penelitian Hukum Normatif, Op.Cit, hlm.25.
} 
tersebut bertentangan dengan Pasal 28 I ayat (5) UUD 1945 yang mewajibkan negara untuk menegakan dan melindungi HAM sesuai prinsip negara hukum yang demokratis yang mengharuskan pelaksanaan HAM dijamin, diatur dan dituangkan dalam peraturan perundang-undangan.

Hukum acara pidana juga mengandung pembatasan-pembatasan terhadap hak asasi manusia melalui sejumlah upaya paksa yang dapat dilakukan oleh aparat penegak hukum terhadap warga negara. Sejumlah ketentuan mengenai upaya paksa yang diatur dalam KUHAP yang Pasal-Pasal tersebut diujikan pemohon dalam putusan Mahkamah Konstitusi ini. Pemohon menyatakan bahwa meskipun ketentuan upaya paksa tersebut telah diatur, namun pengaturan dalam KUHAP tidak dilakukan secara tuntas. Hal ini menyebabkan multitafsir seperti "bukti permulaan", "bukti permulaan yang cukup", dan "bukti yang cukup" sehingga definisinya perlu ditentukan melalui peraturan lain yang bukan Undang-Undang atau bahkan melalui penafsiran aparat penegak hukum terkait, dalam hal ini oleh Hakim Mahkamah Konstitusi.

Pemohon dalam pokok permohonannya menyatakan antara lain:

a. Bahwa Pasal 1 angka 2 KUHAP melanggar Pasal 1 ayat (3) dan Pasal 28 D ayat (1) UUD 1945 karena menimbulkan kesewenaan/g-wenangan yang bertentangan dengan prinsip due process of law serta pelanggaran terhadap hak atas kepastian hukum yang adil.

b. Bahwa Pasal 1 angka 2 KUHAP dapat diinterpretasikan dan diberi makna bahwa seseorang dapat ditetapkan terlebih dahulu sebagai tersangka sebelum adanya penyidikan. Menurut pemohon penyidikan bukan merupakan proses pidana yang mengharuskan lahirnya tersangka pada proses akhir. Penyidikan secara tegas memberikan syarat bahwa penetapan tersangka merupakan tahapan lanjutan yang syaratnya hanya dapat dilakukan setelah penyidik berhasil mengumpulkan buktibukti yang cukup.

c. Bahwa Pasal 1 angka 14 juncto Pasal 17 juncto Pasal 21 ayat (1) KUHAP melanggar Pasal 1 ayat (3), pasal 28 D ayat (1), Pasal 28 I ayat (5) UUD 1945 karena terdapat makna multitafsir sehingga dalam penegakannya menimbulkan kepastian hukum.

d. Frasa "bukti permulaan" Pasal 1 angka 14 KUHAP tidak hanya sebatas Pasal 184 KUHAP tetapi juga meliputi barang bukti dalam pembuktian universal atau physical evidence/real evidence. 
e. Frasa "bukti permulaan yang cukup" Pasal 17 KUHAP menimbulkan perdebatan terkait dua alat bukti, yaitu secara kualitatif atau kuantitatif. Secara kuantitatif adalah dua dari lima alat bukti yang ada dalam Pasal 184 KUHAP. Secara kuantitaif, dua orang saksi sudah dihitung sebagai dua alat bukti.

f. Frasa "bukti yang cukup" Pasal 21 KUHAP mengenai harus ada dua alat bukti secara kualitatif, kecuali perihal keterangan saksi. Artinya, "bukti yang cukup" juga merujuk pada minimum dua alat bukti atas kekhawatiran bahwa tersangka atau terdakwa akan melarikan diri, merusak atau menghilangkan barang bukti atau mengulangi tindak pidana.

g. Pasal 1 angka 14 jucnto Pasal 17 juncto Pasal 21 ayat (1) KUHAP harus diberi makna dan dinyataan inkonstitusional secara bersyarat sepanjang frasa "bukti permulaan", "bukti permulaan yang cukup", dan "bukti yang cukup" harus dimaknai sebagai minimum dua alat bukti secara kualitatif, kecuali dalam hal keterangan saksi.

h. Pasal 77 huruf a KUHAP melanggar Pasal 27 ayat (1), Pasal 28 D ayat (1) UUD 1945 karena konsep praperadilan yang terbatas pada memberikan penilaian terhadap sah atau tidaknya penangkapan, penahanan, penghentian penyidikan atau penghentian penuntutan, jelas tidak sepenuhnya memberikan perlindungan yang cukup bagi tersangka sehingga menimbulkan pelanggaran terhadap hak asasi manusia.

i. Bahwa Pasal 156 ayat (2) KUHAP melanggar Pasal 1 ayat (3) dan Pasal 28 D ayat (1) UUD 1945 karena dapat diinterpretasikan tanpa batasan yang jelas oleh hakim yang memeriksa perkara setelah memberikan putusan sela.

j. Pasal 156 ayat (2) KUHAP bertentangan dengan asas legalitas dan asas peradilan yang cepat. Perlawanan atas penolakan terhadap keberatan terdakwa atau penasehat hukum tidak boleh ditafsirkan harus dilakukan secara bersama-sama dengan banding. Saat berkas perkara dikirimkan kepada Pengadilan Tinggi, maka persidangan harus dihentikan dan hakim wajib mengabulkan perlawanan yang dilakukan oleh terdakwa atau penasehat hukumnya.

Berdasarkan pokok perkara tersebut, pemohon meminta dalam petitumnya agar Hakim untuk memberikan putusan terkait beberapa Pasal di KUHAP, yaitu :

a. Menyatakan frasa "dan guna menemukan tersangkanya" dalam Pasal 1 angka 2 KUHAP bertentangan dengan UUD 1945 secara bersyarat (conditionally 
unconstitusional) dan tidak mempunyai kekuatan hukum mengikat sepanjang tidak dimaknai "dan berdasarkan hasil penyelidikan tersebut untuk kemudian dapat menemukan tersangkanya",

b. Menyatakan frasa "bukti permulaan" dalam Pasal 1 angka 14 KUHAP bertentangan dengan UUD 1945 secara bersayarat (conditionally unconstitutional) dan tidak mempunyai kekuatan hukum mengikat sepanjang tidak dimaknai "sekurang-kurangnya 2 (dua) alat bukti",

c. Menyatakan frasa "melakukan tindak pidana"dan frasa "dalam hal adanya keadaan yang menimbulkan kekhawatiran bahwa tersangka atau terdakwa"dalam Pasal 21 ayat (1) KUHAP bertentangan dengan UUD 1945 dan tidak mempunyai kekuatan hukum mengikat.

d. Menyatakan Pasal 77 huruf a KUHAP bertentangan dengan UUD 1945 secara bersyarat (conditionally unconstitutional) dan tidak mempunyai kekuatan hukum mengikat sepanjang tidak dimaknai mencakup sah atau tidaknya penetapan tersangka, pengeledahan, penyitaan, pemeriksaan surat,

e. Menyatakan frasa "sebaliknya dalam hal tidak diterima atau hakim berpendapat hal tersebut baru dapat diputus setelah selesai pemeriksaan, maka sidang dilanjutkan." Dalam Pasal 156 ayat (2) KUHAP bertentangan dengan UUD 1945 dan tidak mempunyai kekuatan hukum mengikat.

Pasal-Pasal yang diujikan oleh para pemohon berdasarkan pemeriksaan bukti-bukti surat dan pemeriksaan saksi ahli dimuka persidangan, hakim MK pun memberikan pertimbangan dan memberikan putusan terhadap Pasal-Pasal yang dimohonkan oleh para pemohon dengan memberikan beberapa penafsiran. Adapun hakim MK memutuskan dan mengabulkan permohonan pemohon untuk sebagian terkait dengan Pasal-Pasal yang diujikan :

a. Frasa "bukti permulaan", "bukti permulaan yang cukup", dan "bukti yang cukup" sebagaimana ditentukan dalam Pasal 1 angka 14, Pasal 17 dan Pasal 21 ayat (1) Undang-Undang Nomor 8 tahun 1981 tentang Hukum Acara Pidana bertentangan dengan Undang-Undang Dasar Negara Republik Indonesia tahun 1945 sepanjang tidak dimaknai "bukti permulaan", bukti permulaan yang cukup", dan "bukti yang cukup" adalah minimal dua alat bukti yang termuat dalam Pasal 184 UndangUndang nomor 08 tahun 1981 tentang Hukum Acara Pidana; 
b. Frasa "bukti permulaan", "bukti permulaan yang cukup", dan "bukti yang cukup" sebagaimana ditentukan dalam Pasal 1 angka 14, Pasal 17, dan Pasal 21 ayat (1) Undang-Undang nomor 8 tahun 1981 tentang Hukum Acara Pidana tidak mempunyai kekuatan hukum mengikat sepanjang tidak dimaknai bahwa "bukti permulaan", "bukti permulaan yang cukup", dan "bukti yang cukup", adalah minimal dua alat bukti yang termuat dalam Pasal 184 Undang-Undang Nomor 8 Tahun 1981 tentang Hukum Acara Pidana;

c. Pasal 77 huruf a Undang-Undang nomor 8 tahun 1981 tentang hukum acara pidana bertentangan dengan Undang-Undang Dasar Negara Republik Indonesia tahun 1945 sepanjang tidak dimaknai termasuk penetapan tersangka, penggeledahan, dan penyitaan;

d. Pasal 77 huruf a Undang-Undang nomor 8 tahun 1981 tentang Hukum Acara Pidana tidak mempunyai kekuatan hukum mengikat sepanjang tidak dimaknai termasuk penetapan tersangka, penggeledahan, dan penyitaan;

Dalam putusan no 21/PUU-XII/2014 hakim Mahkamah Konstitusi, menyatakan inkonstitusional bersyarat terhadap frasa "bukti permulaan", "bukti permulaan yang cukup", dan "bukti yang cukup" dalam Pasal 1 angka 14, Pasal 17, dan Pasal 21 ayat (1) KUHAP sepanjang dimaknai minimal dua alat bukti sesuai Pasal 184 KUHAP. Pasal 77 huruf a KUHAP dinyatakan inkontitusional bersyarat sepanjang dimaknai termasuk penetapan tersangka, penggeledahan, dan penyitaan.

Hakim Mahkamah Konstitusi memberikan alasan pertimbangannya yaitu KUHAP tidak memberi penjelasan mengenai batasan jumlah (alat bukti) dari frasa "bukti permulaan", "bukti permulaan yang cukup", dan "bukti yang cukup". Berbeda dengan Pasal 44 ayat (2) UU No. 30 Tahun 2002 tentang Komisi Pemberantasan Tindak Pidana Korupsi yang mengatur secara jelas batasan jumlah alat bukti, yakni minimal dua alat bukti. 'Frasa 'bukti permulaan', 'bukti permulaan yang cukup', dan 'bukti yang cukup' dalam Pasal 1 angka 14, Pasal 17, dan Pasal 21 ayat (1) KUHAP harus ditafsirkan sekurang-kurangnya dua alat bukti sesuai Pasal 184 KUHAP disertai pemeriksaan calon tersangkanya, kecuali tindak pidana yang penetapan tersangkanya dimungkinkan dilakukan tanpa kehadirannya (in absentia).

Hakim Mahkamah Konstitusi menyatakan dalam pertimbangan hukumnya bahwa syarat minimum dua alat bukti dan pemeriksaan calon tersangka untuk transparansi dan perlindungan hak asasi seseorang agar sebelum seseorang ditetapkan sebagai tersangka 
telah dapat memberi keterangan secara seimbang. Hal ini menghindari adanya tindakan sewenang-wenang oleh penyidik terutama dalam menentukan bukti permulaan yang cukup itu.

Sementara dalam pranata praperadilan, meski dibatasi secara limitatif dalam Pasal 1 angka 10 jo Pasal 77 huruf a KUHAP. Namun, penetapan tersangka adalah bagian dari proses penyidikan yang terbuka kemungkinan terdapat tindakan sewenang-wenang oleh penyidik yang termasuk perampasan hak asasi seseorang. Memang Pasal 1 angka 2 KUHAP kalau diterapkan secara benar tidak diperlukan pranata praperadilan. Namun jika ada kesalahan dalam proses penetapan seorang menjadi tersangka, maka sudah seharusnnya penetapan tersangka menjadi bagian dari proses penyidikan yang dapat dimintakan perlindungan melalui pranata praperadilan.

Berdasarkan analisa tersebut, maka Hakim Mahkamah Konstitusi telah melakukan penemuan hukum dengan memberikan penafsiran dan batasan apa yang dapat menjadi objek dari praperadilan dalam hukum acara pidana dengan mengujinya terhadap konstitusi dan melihat apakah Pasal-Pasal KUHAP yang diujikan tersebut bertentangan dengan hakhak konstitusional. Meskipun dalam putusan ini terdapat dissenting opinion.

\subsection{Metode Penemuan Hukum Yang Digunakan Hakim MK Dalam Putusan No. 21/PUU-XII/2014}

Menurut penyusun terdapat beberapa teknik interpretasi yang digunakan oleh hakim anggota di dalam putusan Nomor 21/PUU-XII/2014. Dalam keputusan bersama, para hakim menggunakan teknik interpretasi Autentik, Sistematik, Grammatical, Historis, Restriktif Ekstensif dan sosiologis. Hal tersebut dapat dilihat didalam putusan para hakim konstitusi. Para hakim pada amar putusan poin satu menyatakan sebuah frasa yang berarti mengartikan hukum dengan menggunakan teknik grammatical.

Dalam subbab Alasan Berbeda, hakim Patrialis Akbar menurut kami menggunakan metode Interpretasi Sosiologis. Hal ini dikarenakan didalam subbab ini, hakim tersebut menitikberatkan sebuah dampak dari hukum berdasarkan apa-apa yang timbul kepada masyarakat sebagai akibat suatu hukum.

Dalam subbab Dissenting Opinion terdapat 3 hakim yang menggunakan teknik interpretasi yang berbeda pula. Menurut kami para hakim tersebut menggunakan teknik interpretasi diantaranya: 
a. Hakim I Dewa Gede Palguna menggunakan teknik Interpretasi Sistematis karena menurut kami menilai suatu hukum secara sistematik kemudian membuat beberapa kesimpulan dari interpretasi tersebut. Hal ini dapat dilihat di dalam tulisan beliau bahwa beliau memberikan beberapa pengertian tentang praperadilan yang bersumber dari KUHP. Selain itu menurut beliau bahwa tujuan praperadilan adalah melindungi hak asasi manusia. Dalam hal ini melindungi hak asasi tersangka atau terdakwa.

Hak yang hendak dilindungi itu khususnya hak atas kebebasan. Namun bila diperhatikan secara implisit ada dua kepentingan yang hendak dilindungi secara seimbang melalui praperadilan. Yaitu kepentingan tersangka serta kepentingan masyarakat.

b. Hakim Muhammad Alim menurut kami menggunakan interpretasi Autentik karena pendapatnya yang berbeda berangkat dari suatu ketentuan pasal. Pasal tersebut antara lain Pasal 1 Angka 2 Undang-Undang Nomor 8 Tahun 1981 tentang Hukum Acara Pidana. berangkat dari pasal tersebut kemudian beliau berpendapat bahwa apabila prosedur penyidikan sudah benar, maka tanpa memasukkan kewenangan praperadilan untuk memeriksa penetapan menjadi tersangka, sudah benar merupakan penegakan hak asasi manusia. jadi penetapan tersangka sebetulnya bukanlah kewenangan praperadilan asal prosedur yang ditetapkan oleh hukum acara pidana dilaksanakan dengan baik.

c. Hakim Aswanto menurut kami menggunakan interprteasi Restriktif dan Ekstensif karena beliau memperluas pengertian dalam suatu Pasal hingga bagaimana suatu Pasal dan ketentuan dapat berdampak kepada Hak Asasi Manusia namun dibatasi dengan ketentuan Pasal lainnya yang pula membatasi Hak Asasi seseorang. Beliau dalam pendapatnya berangkat dari Pasal 77 KUHAP yang menurut beliau bahwa Pasal 77 KUHAP secara tegas dan limitatif mengatur tindakan hukum apa saja yang dapat diuji pada praperadilan. yakni sah atau tidaknya penangkapan, penahanan, penghentian penyidikan atau penghentian penuntuan serta ganti kerugian dan atau rehabilitasi bagi seseorang perkara yang pidananya dihentikan pada tingkat penyidikan dan penuntuta. didalam ketentuan tersebut tidak diatur mengenai penetapan tersangka. 
Pengaturan secara limitatif dimaksudkan untuk menjamin proses penegakan hukum. Sementara dalam setiap proses hukum, hak asasi seseorang juga harus dijaga sesuai dengan ketentuan UUD 1945. 


\section{PENUTUP}

\subsection{SIMPULAN}

1. Dalam hal kasus ini Hakim Mahkamah Konstitusi telah melakukan penemuan hukum dengan memberikan penafsiran dan batasan apa yang dapat menjadi objek dari praperadilan dalam hukum acara pidana dengan mengujinya terhadap konstitusi dan melihat apakah Pasal-Pasal KUHAP yang diujikan tersebut bertentangan dengan hakhak konstitusional. Meskipun dalam putusan ini terdapat dissenting opinion. Namun, dari hasil putusan hakim yang melalui suatu penafsiran dalam menemukan hukum mengenai objek praperadilan tersebut, dapat dikatakan bahwa Hakim Mahkamah Konstitusi telah menjalankan salah satu fungsi dari Mahkamah Konstitusi yang menyebutkan bahwa salah satu fungsinya adalah melindungi hak-hak konstitusional sebagaimana yang dikemukakan oleh Jimly Asshiddqie.

2. Menurut penyusun terdapat beberapa teknik interpreasi yang digunakan oleh hakim anggota di dalam putusan Nomor 21/PUU-XII/2014. Dalam keputusan bersama, para hakim menggunakan teknik interpretasi Autentik, Sistematik, Grammatical, Historis, Restriktif Ekstensif dan sosiologis. Hal tersebut dapat dilihat didalam putusan para hakim konstitusi. Para hakim pada amar putusan poin satu menyatakan sebuah frasa yang berarti mengartikan hukum dengan menggunakan teknik grammatical

\section{DAFTAR PUSTAKA}

\section{A. BUKU}

Achmad Ali, Menguak Tabir Hukum (Suatu Kajian Filosofis dan Soiologis), Chandra Pratama, Jakarta.

Ahmad Rifai, 2010, Penemuan Hukum Oleh Hakim, Dalam Perspektif Hukum Progresif, Sinar Grafika, Jakarta.

Antonius Sudirman, 2007, Hati Nurani Hakim dan Putusannya, Citra Aditya Bakti, Bandung.

Hamidi, 2005, Hermeneutika Hukum, Teori Penemuan Hukum Baru dengan Interpretasi Teks. UII Press, Yogyakarta.

Jimly asshiddiqie, 2002, "Judicial Review : Kajian atas Putusan Permohonan Hak Uji Materiil terhadap PP No.19 Tahun 2000 tentang TGPTPK”, Jurnal Dictum, Edisi 1. 
Jimly Asshiddiqie, 2007, Pokok - Pokok Hukum Tata Negara Indonesia Pasca Reformasi, PT. Bhuana Ilmu Populer, Jakarta.

Johnny Ibrahim, 2005, Teori dan Metedologi Hukum Normatif, Bayumeia Publishing, Jakarta.

Leonard W. Levy (ed.), Judicial Review : Sejarah Kelahiran, Wewenang dan Fungsinya dalam Nrgara Demokrasi, terjemahan Eni Purwaningsih, Nusamedia dan Nuansa, Bandung.

O.C. Kaligis. 2005, Mahkamah Konstitusi Praktik Beracara \& Permasalahannya. O.C. Kaligis \& Associates: Jakarta.

Philipus M. Hadjon dan Titiek Sri Djatmiati, 2005, Argumentasi Hukum, Univeritas Gajah Mada Press, Yogyakarta.

Pontang Maroed B.M, 2005,Pembentukan Hukum Melalui Putusan Pengadilan Perkara Pidana, Alumni, Bandung.

Sudikno Mertokusumo, 2007, Penemuan Hukum, Sebuah Pengantar, Liberty, Yogyakarta.

Sudikno Mertokusumo dan A. Plito, Bab-Bab tentang Penemuan Hukum, Citra Aditya Bhakti, Jakarta.

Yudha Bhakti Ardiwisastra, 2000, Penafsiran dan Konstruksi Hukum, Alumni, Bandung.

\section{B. LITERATUR LAIN}

http://www.pn-tolitoli.go.id/index.php?option=com_content\&view=article\&id=1 $19 \&$ Itemid $=110$.

http://www.mahkamahkonstitusi.go.id/index.php?page=web.Berita\&id=11779\#.WDC3L6 J95sM.

http://www.hukumonline.com/berita/baca/lt553f5575acd85/mk-rombak-bukti-permulaandan-objek-praperadilan.

Tim Penyusun Hukum Acara Mahkamah Konstitusi, Hukum Acara Mahkamah Konstitusi Jakarta : Sekretariat Jenderal dan Kepaniteraan NKRI, 2010. 